\title{
PERUNDUNGAN REMAJA DI SEKOLAH KATOLIK SWASTA JAKARTA
}

\author{
Rr. Kharesdriani Vacomia ${ }^{1}$, Weny Savitry S. Pandia ${ }^{2}$ \\ ${ }^{1}$ Fakultas Psikologi, Universitas Katolik Indonesia Atma Jaya, Jakarta \\ Email: vacomia83@gmail.com \\ ${ }^{2}$ Fakultas Psikologi, Universitas Katolik Indonesia Atma Jaya, Jakarta \\ Email: weny.sembiring@atmajaya.ac.id
}

Masuk : 22-02-2019, revisi: 13-10-2020, diterima untuk diterbitkan : 31-10-2020

\begin{abstract}
There are several roles when it comes to bullying; the bully, the assistant, the victim, the defender, and the outsider. This study aims to look at an overview of bullying at Catholic schools, especially the roles in bullying, and the efforts that have been taken by the schools to prevent and overcome bullying. Catholic schools are chosen in this study for having values both in learning process and various activities. A mixed method is applied as the research method. Quantitative approach is implemented to identify the role description in students bullying at Catholic schools, and qualitative approach is conducted to perceive the efforts that have been taken by the schools to prevent and overcome bullying at the schools. The study involved 178 students who filled out questionnaires and 15 students in group interviews, as well as 15 teachers from 3 different Catholic schools. The data were processed with SPSS. The observation was conducted by observing the building conditions of school A, B, and C. The result of the study indicates that bullying occurs in Catholic schools and the students take a part in different roles. The biggest percentage is the role of the bully. The interview results with the teachers and the student groups show that the bullying prevention had been carried out by providing various useful activities. Each school has values in educating pupils based on the spirit of the Saint of which are implemented as a fundamental of all activities and in the character building. The schools supervise the students and give mentoring to them if they make mistakes. Nevertheless, regulations against bullying, further information about bullying, and evaluations on implemented programs are still needed.
\end{abstract}

Keywords: bullying, Catholic high school, adolescents

\begin{abstract}
ABSTRAK
Ada beberapa peran dalam hal perundungan: pelaku, asisten pelaku, korban, pembela potensial, dan penonton yang tidak terlibat. Penelitian ini bertujuan untuk melihat gambaran tentang perundungan di sekolah Katolik, khususnya perannya dalam perundungan, dan upaya yang telah dilakukan sekolah untuk mencegah dan menanggulangi perundungan. Sekolah Katolik dipilih dalam penelitian ini karena memiliki nilai-nilai, baik dalam proses pembelajaran maupun dalam berbagai kegiatan. Mixed method diterapkan sebagai metode penelitian. Pendekatan kuantitatif dilakukan untuk mengetahui gambaran peran siswa dalam melakukan perundungan di sekolah Katolik, dan pendekatan kualitatif dilakukan untuk melihat upaya yang telah dilakukan sekolah dalam mencegah dan menanggulangi perundungan di sekolah. Penelitian ini melibatkan 178 siswa yang mengisi kuesioner dan 15 siswa dalam wawancara kelompok, serta 15 guru dari 3 sekolah Katolik yang berbeda. Data diolah dengan SPSS. Observasi dilakukan dengan melihat kondisi sekolah A, B, dan C. Hasil penelitian menunjukkan bahwa perundungan terjadi di sekolah Katolik, dan peran siswa berbeda-beda. Persentase terbesar adalah peran pelaku perundungan. Hasil wawancara dengan guru dan kelompok siswa menunjukkan bahwa pencegahan perundungan telah dilakukan dengan memberikan berbagai kegiatan yang bermanfaat. Setiap sekolah memiliki nilai-nilai dalam mendidik anak didik yang dilandasi oleh semangat Orang Suci yang diimplementasikan sebagai dasar dari semua kegiatan dan pembinaan karakter. Sekolah mengawasi siswa dan memberikan pendampingan jika mereka melakukan kesalahan. Kendati demikian, regulasi yang melarang perundungan, informasi lebih lanjut tentang perundungan, dan evaluasi atas program-program yang dilaksanakan masih diperlukan.
\end{abstract}

Kata Kunci: perundungan, Sekolah Menengah Katolik, remaja

\section{PENDAHULUAN}

\section{Latar belakang}

Perundungan bisa terjadi karena adanya pihak yang lemah dan ada pihak yang lebih kuat. Menurut Coloroso (2002), perundungan merupakan tindakan agresif yang dilakukan pelaku untuk menyakiti korban dan dilakukan dengan kesengajaan untuk membuat korban takut dan merasa 
tersakiti. Ada beberapa jenis perundungan yang terjadi. Berdasarkan Coloroso (2002) perundungan bisa berupa verbal, fisik, dan/atau relasional, yang dapat dimiliki oleh berbagai lapisan ras, etnis, agama, jenis kelamin, seksualitas, identitas seksual, orientasi seksual, kemampuan fisik atau mental, berat badan, alergi, atau status ekonomi.

Dalam perundungan peran yang terlihat adalah pelaku dan korban, namun terdapat peran lain, yaitu asisten pelaku, pembela potensial, dan penonton tidak terlibat. Remaja merupakan masa perubahan dari anak menuju remaja dan mengalami perkembangan baik biologis, kognitif maupun sosial. Perundungan di masa remaja bisa terjadi, terutama di sekolah. Sekolah merupakan tempat memperoleh pendidikan akademis dan berbagai kegiatan bermanfaat. Program intervensi perundungan dibutuhkan sekolah untuk meminimalisir perundungan. Menurut Olweus (1994) penting untuk mencoba menciptakan lingkungan sekolah dan rumah yang ideal, yang ditandai dengan kehangatan, minat positif, dan keterlibatan dari orang dewasa. Di sisi lain perlu ada batasan tegas untuk perilaku yang tidak dapat diterima.

Penelitian ini dilakukan di SMA A, SMA B, dan SMA C yang merupakan sekolah swasta Katolik dengan menerapkan nilai-nilai Katolik dalam mendidik siswa siswi dan sebagai pedoman dalam berperilaku. Sekolah-sekolah ini memiliki program dan kegiatan untuk mendidik siswa-siswa serta usaha mencegah dan mengatasi perundungan. Namun, perilaku perundungan masih ada di sekolah-sekolah tersebut. Di SMA B pernah terjadi 2 kasus perundungan di tahun 2018. Di SMA A, terjadi perundungan 5 tahun lalu. Pada perundungan tersebut ada peran-peran seperti pelaku, asisten pelaku, korban, pembela potensial dan penonton tidak terlibat.

Pemerintah telah membuat program pendidikan karakter yang diajarkan di sekolah dan menetapkan Peraturan Menteri Pendidikan dan Kebudayaan Republik Indonesia Nomor 82 tahun 2013 tentang Pencegahan dan Penanggulangan Kekerasan di Lingkungan Satuan Pendidikan.

Perundungan adalah perilaku agresif yang dilakukan secara terus menerus oleh pelaku kepada korban. Veenstra dalam Sugiariyanti (2005) menyatakan bahwa perundungan merupakan tindakan agresi yang berulang-ulang, yang dilakukan seseorang atau lebih dengan maksud menyakiti atau mengganggu orang lain secara fisik (memukul, menendang, mendorong, mengambil atau merebut sesuatu milik orang lain), secara verbal (mengejek, mengancam), atau secara psikologis (mengeluarkan dari kelompok, mengisolasi, menyebar gosip).

Rigby (2007) menyatakan akan bermanfaat untuk membedakan jenis perilaku perundungan. Perbedaan paling mendasar adalah antara bentuk fisik dan psikologis. Yang pertama termasuk memukul dan menendang; yang terakhir antara lain pelecehan verbal, pemanggilan nama, isyarat mengancam, menguntit, panggilan telepon berbahaya ke rumah siswa, berulang kali menyembunyikan barang milik orang lain, membuat orang keluar dari kegiatan yang diinginkan, dan menyebarluaskan rumor jahat tentang seseorang. Perundungan dapat dilakukan secara langsung, seperti ketika seorang siswa terus-menerus memukul atau mengolok-olok orang lain; atau tidak langsung, seperti menyebarkan cerita tentang seseorang.

Salmivalli dkk (dalam Demaray, Summers, Jenkins, Becker, 2016) menggambarkan pelaku perundungan sebagai individu yang melakukan perundungan dengan menonton, tertawa, atau menggunakan gerakan yang berlebih; asisten pelaku perundungan adalah peserta yang tidak memulai perundungan tetapi akan bergabung ketika orang lain memulai perilaku; pembela korban adalah peserta yang mencoba untuk menghentikan intimidasi dan menghibur korban; dan orang luar adalah peserta yang menghindari intimidasi dan tidak memihak siapa pun. 
Faktor yang dapat mempengaruhi antara lain faktor keluarga, faktor sekolah, faktor media massa, dan teman sebaya. Tumon (dalam Putri, Nauli, \& Novayelinda, 2015) menyatakan secara garis besar faktor yang mempengaruhi perundungan yaitu faktor keluarga, faktor sekolah, dan faktor teman sebaya.

Berdasarkan Neirenberg (dalam Lane, 2015), korban perundungan mungkin mengalami efek jangka pendek dan jangka panjang. Efek jangka pendek terkait perundungan dapat menyebabkan korban mengalami kemarahan, ekspresi ketakutan, kecemasan, dan menghindari tempat di mana perundungan terjadi, insidensi penyakit yang lebih besar, nilai rendah, pikiran dan perasaan ingin bunuh diri. Namun, efek jangka panjang terkait dengan perundungan dapat menyebabkan korban mengalami kesempatan kerja yang berkurang, mengalami perasaan marah dan kepahitan, keinginan untuk membalas dendam, kesulitan mempercayai orang, kesulitan antar pribadi yang meliputi ketakutan dan penghindaran situasi sosial baru, kecenderungan yang meningkat untuk menyendiri, persepsi menjadi sasaran empuk yang mudah, sensitif yang berlebihan, harga diri rendah dan meningkatnya insiden perundungan dan viktimisasi.

\section{Rumusan Masalah}

Dalam penelitian ini ingin dilihat perundungan yang ada di sekolah swasta Katolik, khususnya peran siswa dalam perundungan. Peran dalam perundungan penting untuk diketahui agar pihak sekolah dapat menentukan intervensi yang tepat dalam kasus perundungan. Penelitian ini juga ingin mengetahui upaya yang dilakukan sekolah dalam mencegah dan mengatasi perilaku perundungan yang ada.

\section{METODE PENELITIAN}

Penelitian ini menggunakan pendekatan mixed method (kuantitatif dan kualitatif deskriptif). Data diperoleh dari hasil kuesioner dan wawancara. Observasi dilakukan untuk melihat bagaimana perundungan yang ada di sekolah dan bagaimana kondisi sekolah.

Populasi dalam penelitian ini adalah SMA swasta Katolik yang ada di Jakarta. Subjek penelitian yaitu siswa kelas XI dari beberapa SMA swasta Katolik di Jakarta. Usia subjek antara 14 - 18 tahun. Jumlah subjek penelitian yaitu 178 murid, prosedur yang dilakukan untuk pengumpulan data menggunakan teknik non-probablity sampling dan pengambilan sample menggunakan metode accidental sampling. Peneliti melakukan wawancara kelompok terhadap 4-7 guru dan 4-7 murid di setiap sekolah.

Penelitian menggunakan alat ukur Bullying Participant Behaviors Questionnaire dan melewati proses expert judgement serta face validity. Alat ukur penelitian menggunakan skala likert dengan 5 pilihan jawaban tidak pernah, jarang, kadang- kadang, sering dan selalu. Dari 50 item pertanyaan dapat terlihat peran responden yaitu sebagai pelaku, asisten pelaku, korban, pembela potensial, atau penonton tidak terlibat.

Perhitungan statistik dilakukan dengan menggunakan SPSS (Statistical Package for the Social Sciences) 22 dan analisis hasil pengolahan data statistik deskriptif (descriptive dan frequencies).

Dilakukan wawancara kepada beberapa guru dan beberapa murid berkaitan dengan perundungan di sekolah. Pedoman wawancara dibuat dengan melihat teori yang berhubungan. Observasi dilakukan dengan melihat kondisi masing-masing sekolah. 


\section{HASIL DAN PEMBAHASAN}

Penelitian ini mengambil data dari 3 sekolah yaitu SMA A, B, dan C dengan total responden 178 orang. Responden terbanyak adalah dari SMA C dengan jumlah 61 orang (34,3\%). Responden laki-laki lebih banyak dibandingkan dengan responden perempuan yaitu sebanyak 98 orang $(55,1 \%)$. Usia responden berkisar antara usia 14-18 tahun. Usia 16 tahun merupakan usia yang mendominasi pada penelitian ini yaitu 149 orang (83\%).Profil dari responden penelitian dapat digambarkan dalam tabel 1 di bawah ini.

Tabel 1. Profil responden

\begin{tabular}{llcc}
\hline & Kategori & $\mathbf{n}$ & \% \\
\hline $\mathrm{A}$ & Sekolah: & & \\
& 1) SMA A & 59 & $33,1 \%$ \\
& 2) SMA B & 58 & $32,6 \%$ \\
& 3) SMA C & 61 & $34,3 \%$ \\
$\mathrm{~B}$ & & \\
& Jenis Kelamin & & $55,1 \%$ \\
& 1) Laki-laki & 98 & $44,9 \%$ \\
& 2)Perempuan & 80 & $0,6 \%$ \\
$\mathrm{C}$ & Usia & 1 & $7,9 \%$ \\
& 1) 14 tahun & 14 & $83 \%$ \\
& 2) 15 tahun & 149 & $6,7 \%$ \\
& 3) 16 tahun & 12 & $1,1 \%$ \\
\hline
\end{tabular}

Peran pelaku dalam perundungan memiliki nilai rata-rata terbesar $(M=24.09, S D=4.82)$. Terkait dengan perundungan ada kecenderungan 53 responden $(29,8 \%)$ untuk menjadi pelaku. Peran asisten pelaku memiliki nilai rata-rata yang terkecil $(M=18.25, S D=5.72)$. Dengan demikian untuk penilaian peran asisten pelaku hanya terdapat 7 orang $(3,9 \%)$ yang teridentifikasi dan ada kecenderungan menjadi asisten pelaku. Tabel 2 berikut ini menunjukkan masing-masing peran dalam perundungan.

Tabel 2. Hasil perhitungan peran

\begin{tabular}{ccccc}
\hline Peran & $\boldsymbol{M}$ & $\boldsymbol{S D}$ & $\mathbf{n}$ & \% \\
\hline Pelaku & 24,09 & 4,82 & 53 & $29,8 \%$ \\
Asisten pelaku & 18,25 & 5,72 & 7 & $3,9 \%$ \\
Korban & 21,67 & 5,20 & 24 & $13,5 \%$ \\
Pembela Potensial & 23,03 & 6,36 & 49 & $27,5 \%$ \\
Penonton tidak terlibat & 22,20 & 6,41 & 45 & $25,3 \%$ \\
\hline
\end{tabular}

Dari semua responden, kecenderungan untuk menjadi korban perundungan sebanyak 24 orang $(13,5 \%)$. Peran pembela potensial ditemukan pada 49 orang, hal ini mengindikasikan dari semua responden yang berpotensi menjadi pembela potensial sebanyak 49 orang $(27,5 \%)$.

Peran penonton tidak terlibat ditemukan pada 45 orang (35,3\%). Dapat diidentifikasi bahwa dari semua responden yang ada kecenderungan menjadi penonton tidak terlibat adalah 45 orang. 
Tabel berikut ini untuk melihat gambaran peran di tiap jenis kelamin.

Tabel 3. Peran berdasarkan jenis kelamin

\begin{tabular}{ccccc}
\hline Peran & Jenis kelamin & $\mathbf{N}$ & $\boldsymbol{M}$ & SD \\
\hline \multirow{2}{*}{ Pelaku } & $\mathrm{L}$ & 98 & 25,19 & 4,60 \\
\cline { 2 - 5 } & $\mathrm{P}$ & 80 & 22,75 & 4,77 \\
\cline { 2 - 5 } Asisten pelaku & $\mathrm{L}$ & 98 & 20,59 & 5,83 \\
\cline { 2 - 5 } & $\mathrm{P}$ & 80 & 15,38 & 4,05 \\
\hline \multirow{2}{*}{ Korban } & $\mathrm{L}$ & 98 & 22,68 & 5.23 \\
\cline { 2 - 5 } & $\mathrm{P}$ & 80 & 20,45 & 4,92 \\
\hline \multirow{2}{*}{ Pembela potensial } & $\mathrm{L}$ & 98 & 23,23 & 6,25 \\
\cline { 2 - 5 } & $\mathrm{P}$ & 80 & 22,78 & 6,52 \\
\hline \multirow{2}{*}{ Penonton tidak terlibat } & $\mathrm{L}$ & 98 & 22,35 & 5,97 \\
\cline { 2 - 5 } & $\mathrm{P}$ & 80 & 22,01 & 6,94 \\
\hline
\end{tabular}

Tabel di atas menunjukkan perbandingan nilai rata-rata dari peran pelaku $(M=25.19, S D=4.60)$, asisten pelaku $(M=20.59, S D=5.83)$, dan korban $(M=22.68, S D=5.23)$ antara jenis kelamin laki-laki lebih tinggi dari pada perempuan. Dapat disimpulkan bahwa laki-laki memiliki kecenderungan yang lebih besar untuk menjadi pelaku, asisten pelaku dan korban dibandingkan perempuan. Tetapi jika dilihat dari peran pembela potensial dan penonton tidak terlibat, nilai ratarata untuk laki-laki dan perempuan tidaklah jauh berbeda perbandingannya dan dapat dikatakan bahwa baik laki-laki maupun perempuan memiliki kecenderungan bisa menjadi pembela potensial ataupun penonton potensial.

Dalam masing-masing peran, terdapat keterkaitan satu sama lain dan dapat dilihat dari tabel 4 di bawah ini.

Tabel 4. Hubungan masing-masing peran

\begin{tabular}{cccccc}
\hline Peran & PLK & AST & KRB & PMB & PNT \\
\hline PLK & - & $.539^{* *}$ & $.302^{* *}$ & -.137 & $.158^{*}$ \\
AST & - & - & $.383^{* *}$ & -.032 & .146 \\
KRB & - & - & - & $.288^{* *}$ & .097 \\
PMB & - & - & - & - & -.044 \\
\hline
\end{tabular}

Catatan: PLK $=$ Pelaku;AST $=$ Asisten Pelaku; KRB $=$ Korban $;$ PMB $=$ Pembela Potensial PNT $=$ Penonton Tidak

Terlibat. **p $<.01,{ }^{*} p>.05$

Dari tabel 4 di atas dapat disimpulkan bahwa ada hubungan yang signifikan positif antara pelaku dengan asisten pelaku, korban dan penonton tidak terlibat. Dengan semakin tinggi kecenderungan sebagai pelaku berarti semakin tinggi juga kecenderungan menjadi asisten pelaku, korban, dan penonton tidak terlibat.

Ada hubungan yang signifikan positif antara asisten dengan korban. Dengan semakin tinggi kecenderungan sebagai asisten berarti semakin tinggi juga kecenderungan menjadi korban. Ada hubungan yang signifikan positif antara korban dengan pembela potensial. Dengan semakin tinggi kecenderungan sebagai korban berarti semakin tinggi juga kecenderungan menjadi pembela potensial.

Wawancara dilakukan secara berkelompok kepada guru dan murid di SMA A, SMA B dan SMA

C. Tabel 5 berikut ini rincian partisipan dari tiap sekolah. 
Tabel 5. Gambaran umum partisipan wawancara

\begin{tabular}{ccc}
\hline Sekolah & Guru & Murid \\
\hline SMA A & 7 & 7 \\
SMA B & 4 & 4 \\
SMA C & 4 & 4 \\
\hline
\end{tabular}

Dari SMA A ada 7 guru yang menjadi partisipan wawancara kelompok yang merupakan guru bidang studi tertentu (guru olahraga, guru bahasa Ingris, guru akuntansi, guru BK, dan lainnya). Di SMA B, terdapat 4 partisipan yang merupakan guru moderator. Guru moderator merupakan guru yang berhubungan dengan siswa- siswi dan menangani permasalahan yang ada pada siswasiswi. Guru-guru tersebut juga merupakan guru bidang studi (guru sejarah, guru sosiologi, guru olah raga). Terdapat 4 guru SMA $\mathrm{C}$ yang menjadi partisipan wawancara. Guru-guru tersebut merupakan guru-guru bidang studi (guru olahraga, guru dan fisika).

Pada SMA A terdapat 7 anak yang menjadi partisipan wawancara kelompok. Anak-anak tersebut kelas XI, dan dipilih oleh guru BK. Untuk SMA B terdapat 4 anak yang menjadi partisipan. Wakil kepala sekolah bagian kesiswaan membantu dalam memilih anak sebagai partisipan wawancara kelompok. Anak-anak yang terpilih sebagai partisipan merupakan anak anak yang terbiasa memegang kegiatan di sekolah. Untuk SMA C terdapat 4 anak yang menjadi partisipan dan dipilih oleh Wakil Kepala Sekolah bagian Humas.

Dari wawancara yang dilakukan, diperoleh hasil bahwa ketiga sekolah tersebut memiliki berbagai macam kegiatan yang bertujuan untuk mengembangkan dan membentuk karakter murid serta memiliki berbagai kegiatan untuk mencegah murid-murid melakukan kegiatan yang tidak bermanfaat.

SMA A, B, dan C belum memiliki peraturan khusus tentang perundungan. Ketiga sekolah ini memiliki cara yang sama dalam menangani murid yang bermasalah. Sekolah melakukan pendampingan kepada murid dan diproses sesuai aturan yang berlaku jika murid melakukan kesalahan. Pihak sekolah juga melakukan pengawasan terhadap perilaku murid-murid di sekolah. Telah terjalin kerjasama antara orang tua dan pihak sekolah. Komunikasi antara pihak sekolah dan orang tua cukup baik sehingga baik orang tua dan sekolah saling mengetahui perkembangan anak.

Murid-murid dari sekolah A, B, dan C telah mengetahui makna perundungan, jenis perundungan, dan penyebab perundungan. Murid-murid juga terlibat aktif dalam berbagai kegiatan yang ada di sekolah. Hanya saja, kegiatan workshop ataupun seminar yang berhubungan dengan perundungan di ketiga sekolah belum ada.

Murid-murid dari ketiga sekolah menyatakan bahwa tidak ada senioritas, semua siswa yang ada di sekolah memiliki kedudukan yang sama. Konflik di sekolah ada, tetapi bukan konflik besar. Biasanya murid-murid berupaya menyelesaikan sendiri terlebih dahulu masalahnya dengan cara yang baik.

Murid-murid juga mengetahui ada sanksi yang harus dilakukan jika melakukan kesalahan. Pendidikan karakter di sekolah yang murid-murid dapatkan yaitu melalui pendidikan agama dan bimbingan konseling.

Hasil penelitian menunjukkan bahwa jumlah pelaku lebih banyak dibandingkan peran yang lainnya. Dapat diartikan bahwa siswa masih banyak yang melakukan perundungan. Terdapat juga 
peran asisten yang menunjukkan siswa ikut terlibat dan membantu pelaku pada saat perundungan. Ada juga peran korban yang menunjukkan bahwa siswa ada yang pernah menjadi korban perundungan. Adanya partisipan yang memiliki peran sebagai pembela potensial menunjukkan masih ada orang yang peduli terhadap temannya. Peran penonton tidak terlibat juga ada, yang menunjukkan bahwa masih ada murid-murid yang tidak peduli dengan kejadian perundungan, tidak menolong korban, ataupun pelaku dan tidak kepada pihak sekolah. Peran-peran itu menunjukkan apa yang dilakukan murid-murid ketika perundungan terjadi. Pengaruh teman sebaya juga dapat menjadi faktor perundungan. Lestari (2016) menyatakan anak-anak ketika berinteraksi dalam sekolah dan dengan teman di sekitar rumah, kadang kala terdorong untuk melakukan perundungan. Beberapa anak melakukan perundungan hanya untuk membuktikan kepada teman sebayanya agar diterima dalam kelompok tersebut, walaupun sebenarnya mereka tidak nyaman melakukan hal tersebut. Pelaku tidak mengetahui bahwa yang dilakukan merupakan tindakan perundungan dan asisten pelaku mengikuti yang dilakukan oleh pelaku. Hal ini terjadi karena kurangnya pengetahuan dan informasi tentang perundungan.

Perundungan terjadi pada sekolah katolik karena peraturan yang kurang jelas. Dengan demikian perlu ada bentuk kerjasama atau komite sekolah yang dapat menjadi sarana mengkomunikasikan permasalahan yang terjadi pada murid.

Pada SMA A, B, dan C, upaya pencegahan perundungan sudah dilakukan dengan memberikan kegiatan-kegiatan bermanfaat kepada murid-murid dan pengawasan serta pendampingan untuk melihat perilaku murid di sekolah. Namun SMA A, B, dan C belum memiliki peraturan tentang perundungan. Faktor sekolah juga mempengaruhi dalam perilaku perundungan. Levianti dalam Lestari (2016) menyatakan perundungan dapat terjadi di sekolah jika pengawasan dan bimbingan etika dari para guru rendah, sekolah dengan kedisiplinan yang sangat kaku, bimbingan yang tidak layak dan peraturan yang tidak konsisten.

Coloroso (2002) menyebutkan bahwa ada tiga hal yang bisa digunakan dalam mencegah perundungan yaitu peraturan, prosedur, dan program. Program tentang perundungan seperti workshop atau seminar tentang perundungan belum pernah dilakukan. Perlunya program workshop atau seminar tentang perundungan bertujuan untuk memberikan informasi kepada pihak sekolah, orang tua, dan murid-murid.

Dalam penelitian ini, wawancara merupakan metode yang digunakan untuk mengetahui perundungan yang ada di sekolah dari pihak sekolah dan murid-murid. Berdasarkan hasil wawancara dengan guru, dari ketiga sekolah memiliki berbagai kegiatan untuk pencegahan terjadinya perundungan di sekolah dan sekolah memiliki nilai-nilai dan peraturan yang mengatur perilaku murid-murid di sekolah. Jika ada siswa bermasalah, sekolah dan guru melakukan pendampingan tetapi untuk perundungan belum ada aturan khusus. Peran orang tua juga penting untuk perkembangan siswa atau siswi di sekolah, ada komunikasi dan kerjasama antar pihak sekolah dan orang tua untuk perkembangan siswa-siswi.

Kesimpulan dari hasil wawancara murid adalah murid sudah mengetahui makna perundungan. Murid-murid mengatakan belum ada workshop atau seminar tentang perundungan secara khusus, sehingga murid-murid belum begitu paham peran-peran yang ada dalam perundungan. Di sekolah ada peraturan dan sanksi ketika murid-murid melakukan kesalahan. Belum ada peraturan secara khusus untuk perundungan, perlu dibuat peraturan secara khusus untuk perundungan sehingga murid-murid tidak melakukan perundungan di sekolah dan jika melakukan perundungan akan ada sanksi dari sekolah. Ada pendidikan karakter yang diberikan sekolah seperti pendidikan budi 
pekerti dan pendidikan agama. Pendidikan karakter dibutuhkan untuk membentuk karakter murid murid. Ini juga merupakan tindakan pencegahan agar perundungan tidak terjadi di sekolah.

Metode wawancara ini merupakan metode penelitian yang melengkapi hasil kuesioner. Dari kuesioner dapat dilihat kecenderungan murid-murid akan memilih peran apa di dalam perundungan. Dari hasil wawancara guru, untuk melihat bagaimana pihak sekolah menanggapi perundungan di sekolah, apakah ada tindakan pencegahan seperti pendidikan karakter dan penanaman nilai-nilai yang ada di sekolah, apakah ada program khusus seperti seminar/ workshop tentang perundungan, kegiatan-kegiatan apa yang dapat mencegah terjadinya perundungan, bagaimana hubungan pihak sekolah, apakah ada komunikasi antara sekolah dan orang tua dalam perkembangan murid. Di sekolah juga perlu dipastikan apakah telah ada peraturan yang mengatur tentang perundungan, jika terjadi perundungan apakah ada sanksi dan bagaimana pihak sekolah menghadapi masalah perundungan.

Wawancara yang dilakukan kepada murid-murid untuk melihat bagaimana murid-murid menanggapi tentang perundungan, apakah murid-murid mengetahui makna perundungan dan bagaimana kegiatan/program sekolah, apakah ada kegiatan/program khusus untuk sarana pengetahuan tentang perundungan. Murid-murid apakah mengetahui tentang sanksi/peraturan yang ada di sekolah, apakah ada sanksi/peraturan khusus yang mengatur tentang perundungan di sekolah. Untuk pendidikan karakter, apakah murid-murid mengetahui pendidikan karakter atau penanaman nilai-nilai apa yang ada di sekolah yang dapat mencegah terjadinya perundungan.

\section{KESIMPULAN DAN SARAN}

Perundungan di sekolah katolik swasta masih ada, dengan peran sebagai pelaku, asisten pelaku, korban, pembela potensial, dan penonton tidak terlibat. Peran pelaku cukup tinggi dibandingkan dengan peran asisten pelaku, korban, pembela potensial dan penonton tidak terlibat. Peran pelaku cukup tinggi karena pelaku tidak mengetahui yang dilakukan merupakan perundungan dan kurangnya informasi tentang perundungan.

Ada penanaman nilai-nilai, kegiatan-kegiatan yang diberikan, namun dalam kehidupan seharihari perlu lebih ditingkatkan dan dengan melakukan evaluasi program-program yang diberikan. Sekolah telah melakukan pendampingan kepada anak-anak ketika anak mengalami masalah. Ada prosedur yang dilakukan jika anak melakukan kesalahan. SMA A, B dan C belum memiliki peraturan tentang perundungan, untuk pencegahan dan penanganan dibutuhkan aturan yang jelas. Hubungan sekolah dengan orang tua juga cukup baik sehingga ada komunikasi untuk guru, orang tua dan murid. Tetapi tidak ada pengetahuan khusus yang diberikan tentang perundungan bagi guru dan orang tua, murid.

Diharapkan agar anak-anak, guru, dan orang tua memiliki pengetahuan tentang perundungan. Sekolah bisa memberikan workshop atau seminar agar pihak sekolah baik guru maupun murid serta orang tua dapat mengetahui seperti apa perundungan, peran-peran apa saja yang ada pada perundungan, dan bagaimana mencegah atau mengatasi perundungan. Perlu dibuat dan dipertegas tentang peraturan perundungan. Program-program yang ada perlu dievaluasi, dari programprogram tersebut dapat dilihat apakah program tersebut efektif atau tidak.

Saran untuk penelitian selanjutnya adalah melakukan pengembangan alat ukur. Untuk responden dapat diperbanyak dengan menambahkan siswa-siswi dari beberapa sekolah sebagai responden penelitian, sehingga memperoleh data dan hasil yang lebih bervariasi, serta mendapatkan suatu hasil yang lebih dalam. Selain itu, untuk wawancara, peneliti selanjutnya bisa menambahkan 
responden yang lebih banyak seperti mewawancara orangtua sehingga didapatkan data dari orangtua.

\section{Ucapan Terima Kasih (Acknowledgement)}

Terima kasih kepada semua pihak yang membantu dalam penelitian khususnya responden yang bersedia meluangkan waktu dalam pengisian alat ukur dan wawancara. Terima kasih juga kepada pihak sekolah $\mathrm{A}, \mathrm{B}$, dan $\mathrm{C}$ yang bersedia memberi kesempatan untuk dilakukan penelitian di sekolah-sekolah tersebut.

\section{REFERENSI}

Coloroso, B. (2002). The bully, the bullied, and the not so innocent bytander. New York: Happer Collins Publisher.

Demaray, M; Summers, K; Jenkins, L; Becker, L. (2016). Bullying participant behaviors questionnaire (BPBQ): Establishing a reliable and valid measure, Journal of School Violence, 15(2), 158-188.

Lane, V. (2015). The relationship between the experiences of bullying and the perception of the harm of bullying in middle schools. (Doctoral dissertation, Capella University, East Eisenhower Parkway, United Stated). Retrived from : https://search.proquest.com/docview/1735405453/E90AA1BD282E40EBPQ/1?accountid= 48149

Lestari, W S. (2016). Analisis faktor faktor penyebab bullying di kalangan peserta didik. Social Science Education Journal, 3(2), 147-157.

Olweus, D (1994). Bullying at school: basic facts and an effective intervention programme. Promotion \& Education, 1(4), 27- 31.

Putri, H N; Nauli, F A; \& Novayelinda, R. (2015). Faktor- faktor yang berhubungan dengan perilaku bullying pada remaja. Jurnal of Medicine, 2(2), 1149 - 1159.

Rigby, K. (2007). Bullying in schools and what to do about it. Australia: ACER press.

Sugiariyanti. (2005). Perilaku bullying pada anak dan remaja. Jurnal Ilmiah Psikologi, 1(2), 101108.

Smith, P K; Pepler, D; \& Rigby, K. (2007). Bullying in schools : How successful can interventions be? New York: Cambridge University Press. 